\title{
COMPARATIVE EVALUATION OF PROPERTIES OF HIGH-STRENGTH N-A-XTRA-70 STEEL WELDED JOINTS PRODUCED USING ARC, LASER AND HYBRID LASER-ARC METHOD
}

\author{
V.D. POZNYAKOV, V.D. SHELYAGIN, S.L. ZHDANOV, A.V. BERNATSKY and A.V. SIORA \\ E.O. Paton Electric Welding Institute, NASU \\ 11 Kazimir Malevich Str., 03680, Kiev, Ukraine. E-mail: office@paton.kiev.ua
}

\begin{abstract}
In the work the comparative evaluation of mechanical properties of butt welded joints of N-A-XTRA-70 high-strength steel of $8 \mathrm{~mm}$ thickness, produced using arc, laser and hybrid laser-arc welding, was carried out. Mechanical tests on static tension and impact bending with V-notch showed that the values of static strength are increased with decrease in heat input of arc welding, and the values of ductility remain almost unchanged. At the same time, the values of impact toughness of weld and HAZ metal are approximately 1.5-1.8 times reduced. This is connected with the fact that at increase in welding speed from 18 to $50 \mathrm{~m} / \mathrm{h}$ the phase composition of weld metal changes from ferrite-bainite to bainite-martensite. In laser welding, the values of static strength of weld metal are by $18-20 \%$ reduced and the ductility 1.8 times increases with increase in welding speed and cooling rate of HAZ metal. With increase in speed of laser welding from 40 to $50 \mathrm{~m} / \mathrm{h}$ the phase composition of weld metal changes from martensite to martensite-bainite (with martensite fraction exceeding $60 \%$ ). In hybrid welding, the increase in welding speed leads to 10-15\% increase in the values of static strength and ductility. These changes occur because of the fact that the fraction of phase components changes. In the molten metal of specimens produced using laser method, and in the deposited metal produced using arc and hybrid methods the ultra-low concentrations of diffusion hydrogen content are observed, namely $0.07,0.2-0.3$ and $0.4 \mathrm{ml} / 100$ g, respectively. 10 Ref., 1 Table, 1 Figure.
\end{abstract}

Ke y words: high-strength steel, butt joints, arc welding, laser welding, hybrid laser-arc welding, mechanical properties, diffusion hydrogen

The high-strength low-alloyed steels with yield strength of 600-900 MPa are used for manufacture of heavy-loaded welded structures in construction and mechanical engineering [1-4]. Their application provides reduction in mass of structures, increases service reliability and longevity of machines, mechanisms and constructions. Especially the use of highstrength steels in manufacture of handling machinery is effective.

The metallurgical processes of HSLA steel welding should meet two basic requirements: provide minimum saturation of weld metal with hydrogen, and producing the weld metal with optimal chemical composition of limited content of carbon and harmful impurities (sulfur and phosphorus) and nonmetallic inclusions [1]. Both requirements are connected, first$1 y$, with the need in preventing the cold crack formation in the metal of different welded joint zones and, secondly, with the need in producing weld and HAZ metal with sufficiently high level of mechanical properties.

In the recent years in the world in order to reduce deformations and improve the quality of welded thinwall metal structures for manufacture of products of steels of ferritic-pearlite class the technological processes are ever widely offered based on the use of laser and hybrid laser-arc welding methods [5-10]. In our opinion, this approach may be acceptable also for welding of high-strength bainite-martensite steels. However, considering the fact that these steels are prone to formation of hardening structures and have an increased tendency to delayed fracture, which is intensified under the influence of diffusion hydrogen, it becomes necessary to investigate the features of weld metal saturation with hydrogen, running of thermodeformational cycles in laser and HLA welding process as compared to the arc process and to establish their effect on the structure and properties of welded joints of high-strength bainite-martensite steels.

The aim of this work is the comparative evaluation of properties of butt joints of N-A-XTRA-70 high-strength steel (wt.\%: $0.15 \mathrm{C}$; $0.63 \mathrm{Si} ; 0.85 \mathrm{Mn}$; $0.65 \mathrm{Cr} ; 0.12 \mathrm{Ni} ; 0.13 \mathrm{Mo} ; 0.04 \mathrm{Al} ; 0.01 \mathrm{~S} ; 0.015 \mathrm{P}$; $\left.0.015 \mathrm{~N}_{2}\right) 8 \mathrm{~mm}$ thick welded using arc, laser and hybrid method. In arc welding, solid wire Union NiMoCr (wt.\%: 0.17 C; $0.53 \mathrm{Si} ; 1.68 \mathrm{Mn} ; 0.12 \mathrm{Cr}$; $1.54 \mathrm{Ni} ; 0.62 \mathrm{Mo} ; 0.011 \mathrm{~S} ; 0,017 \mathrm{P}$ ) of $1 \mathrm{~mm}$ diameter was used. The welding was performed at $I_{\mathrm{w}}=$ 
$=230-250 \mathrm{~A}, U_{\mathrm{a}}=28-32 \mathrm{~V}$ in the gas mixture of $\mathrm{Ar}+$ $18 \% \mathrm{CO}_{2}$, at $v_{\mathrm{w}}=18,30,40$ and $50 \mathrm{~m} / \mathrm{h}$.

Laser welding without filler metal was carried out in the mixture of $\mathrm{Ar}+18 \% \mathrm{CO}_{2}$, at $v_{\mathrm{w}}=40$ and $50 \mathrm{~m} / \mathrm{h}$, power of laser radiation $P=4.4 \mathrm{~kW}$ and defocusing $\Delta F=-2 \mathrm{~mm}$.

In HLA welding solid wire Union NiMoCr of $1 \mathrm{~mm}$ diameter was used. The welding was performed in the mixture of $\mathrm{Ar}+18 \% \mathrm{CO}_{2}$, at $v_{\mathrm{w}}=72$ and $90 \mathrm{~m} / \mathrm{h}, P=$ $=4.4 \mathrm{~kW}, \Delta F=-1.5 \mathrm{~mm}, I_{\mathrm{w}}=120-130 \mathrm{~A}$, and $U_{\mathrm{a}}=$ $=22-24 \mathrm{~V}$.

For welded joints, produced with equal value of heat input $Q_{\mathrm{w}} \sim 3 \mathrm{~kJ} / \mathrm{cm}$, in case of application of laser welding (Figure 1,a) the volume of remelted metal is lower than that in hybrid welding (Figure $1, b$ ). This is explained by occurring of the so-called hybrid effect consisting in non-additivity of the combined effect of laser and arc power sources on the material being welded [8].

To investigate the influence of thermal cycles on the structure and properties of HAZ metal of welded joints of steel N-A-XTRA-70 the works were carried out on fixation of heating and cooling processes in laser and hybrid welding. The results of the carried out experiments evidence that the cooling rate in the temperature range of $600-500{ }^{\circ} \mathrm{C}$ in HLA welding is about $61-63{ }^{\circ} \mathrm{C} / \mathrm{s}$, and in laser welding $w_{6 / 5}=65-103{ }^{\circ} \mathrm{C} / \mathrm{s}$.

To carry out mechanical tests the specimens on static tension were manufactured from welded joints (type I according to GOST 6996-66) and impact bending (type XI according to GOST 6996-66) with $\mathrm{V}$-notch. The specimens were tested on tension at room temperature, and on impact strength at $20,-20$ and $-40{ }^{\circ} \mathrm{C}$.

The carried out mechanical tests showed (the Table) that with decrease in heat input of arc welding
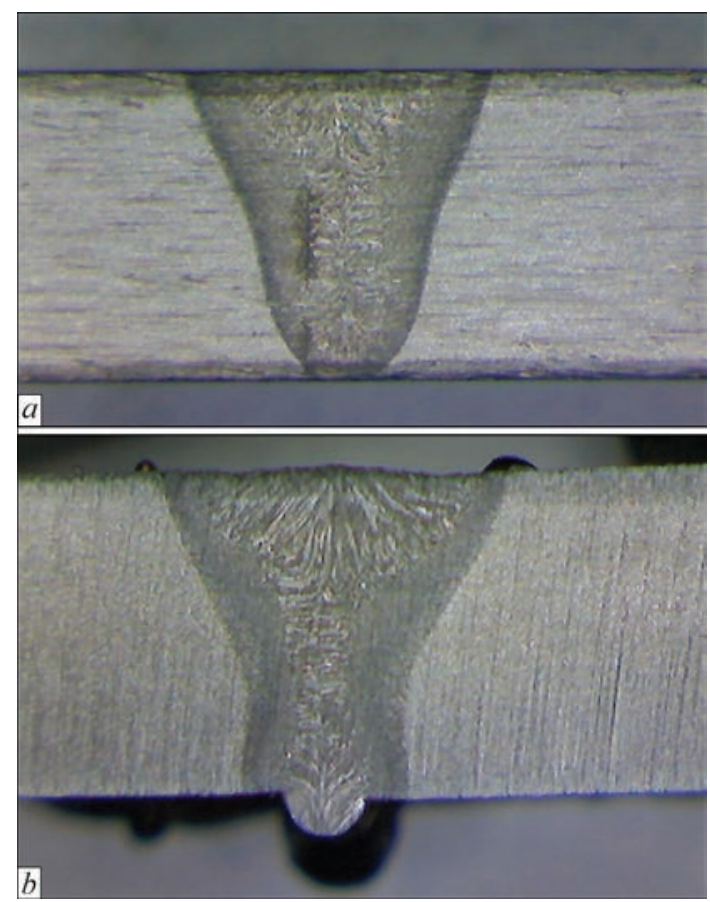

Macrostructure of cross sections of butt welded joints of N-AXTRA-70 steel $(\delta=8 \mathrm{~mm})$ produced using laser $(a)$ and hybrid laser-arc $(b)$ methods at equal $Q_{\mathrm{w}}=3 \mathrm{~kJ} / \mathrm{cm}$

the values of static strength $\sigma_{0.2}$ increase from $\sim 731$ to $\sim 822 \mathrm{MPa}$ and $\sigma_{\mathrm{t}} \sim 817-910 \mathrm{MPa}$, and the values of ductility are almost unchanged and amount on average to $\delta_{5} \sim 19 \%$, and $\psi \sim 63 \%$. At the same time, the values of impact toughness of weld and HAZ metal are approximately $1.5-1.8$ times decreased. As the results of metallographic analysis show, it is connected with the fact that with increase in welding speed from 18 to $50 \mathrm{~m} / \mathrm{h}$, the phase composition of weld metal is changed from ferrite-bainite to bainite-martensite and the microhardness increases by $30 \%$.

The results of carried out investigations of influence of laser and HLA welding conditions on mechanical properties of weld metal and welded joints of

Mechanical properties of base N-A-XTRA-70 steel metal and welded joints produced using arc, laser and hybrid laser-arc welding with wire Union NiMoCr of $1 \mathrm{~mm}$ diameter in the $\mathrm{Ar}+\mathrm{CO}_{2}$ mixture

\begin{tabular}{|c|c|c|c|c|c|c|c|c|c|c|}
\hline \multirow{3}{*}{$\begin{array}{c}\text { Object of } \\
\text { investigation } \\
\left(\text { method; } v_{\mathrm{w}}, \mathrm{m} / \mathrm{h}\right)\end{array}$} & \multirow[b]{2}{*}{$\sigma_{0.2}$} & \multirow{2}{*}{$\sigma_{\mathrm{t}}$} & \multirow{2}{*}{$\delta_{5}$} & \multirow{2}{*}{$\psi$} & \multicolumn{6}{|c|}{$K C V, \mathrm{~J} / \mathrm{cm}^{2}$, at $T,{ }^{\circ} \mathrm{C}$} \\
\hline & & & & & +20 & -20 & -40 & +20 & -20 & -40 \\
\hline & \multicolumn{2}{|c|}{$\mathrm{MPa}$} & \multicolumn{2}{|c|}{$\%$} & \multicolumn{3}{|c|}{ Weld } & \multicolumn{3}{|c|}{ HAZ } \\
\hline BM & 790.0 & 850.0 & 18.3 & 66.0 & N/D & N/D & 50.0 & N/D & N/D & N/D \\
\hline WJ (AW; 18) & 731.1 & 817.1 & 19.5 & 65.0 & 181.6 & - & 109.2 & 217.9 & - & 218.0 \\
\hline WJ (AW; 30) & 777.7 & 871.0 & 19.7 & 63.2 & 145.7 & - & 81.6 & 232.7 & - & 223.1 \\
\hline WJ (AW; 40) & 826.7 & 915.0 & 18.4 & 60.9 & 140.3 & - & 91.3 & 246.3 & - & 212.3 \\
\hline WJ (AW; 50) & 822.0 & 905.0 & 18.8 & 64.5 & 138.9 & - & 93.7 & 242.6 & - & 213.5 \\
\hline WJ (LW; 40) & 1043.9 & 1227.7 & 6.0 & 24.9 & N/D & 15.5 & 8.7 & 90.6 & 84.0 & 59.2 \\
\hline WJ (LW; 50) & 854.5 & 1050.8 & 10.0 & 42.4 & 52.5 & 13.8 & 7.3 & N/D & N/D & N/D \\
\hline WJ (HLAW; 72) & 961.0 & 1196.0 & 6.2 & 28.0 & 113.0 & 83.4 & 59.1 & 102.5 & 102.3 & 76.8 \\
\hline WJ (HLAW; 90) & 1082.0 & 1259.0 & 9.3 & 33.3 & 113.1 & N/D & 72.5 & 94.3 & N/D & 72.6 \\
\hline
\end{tabular}


N-A-XTRA-70 high-strength steel of $8 \mathrm{~mm}$ thickness prove (see the Table) that in laser welding the values of static strength of weld metal are reduced by $18-20 \%$ and the values of ductility are 1.8 times increased with increase in welding speed and cooling rate of HAZ metal. The results of metallographic examinations show that with increase in speed of laser welding from 40 to $50 \mathrm{~m} / \mathrm{h}$ the phase composition of weld metal changes from martensite to martensite-bainite (with martensite fraction exceeding $60 \%$ ).

In HLA welding, the increase in welding speed leads to $10-15 \%$ increase in the values of static strength. As the results of metallographic examinations show, these changes occur because of the fact that the share of phase components changes: at $v_{\mathrm{w}}=72 \mathrm{~m} / \mathrm{h}$, $\mathrm{B}_{\mathrm{L}}>\mathrm{B}_{\mathrm{U}}+\mathrm{M}$; at $v_{\mathrm{w}}=90 \mathrm{~m} / \mathrm{h}, \mathrm{B}_{\mathrm{L}}<\mathrm{B}_{\mathrm{U}}+\mathrm{M}$.

The investigations on determination of diffusion hydrogen in the deposited metal during arc, laser and hybrid welding were carried out using chromatographic method. The specimens of $25 \times 15 \times 15 \mathrm{~mm}$ with deposited and molten metal were cooled in liquid nitrogen and then placed to the chromatograph chamber for the analysis of the evolved hydrogen content. Due to the fact that laser welding was carried out without the filler wire, it is not possible to attribute the volume of released hydrogen to the weight of deposited metal. Taking into account the latter, the content of diffusion hydrogen in the metal was determined according to its volume in the molten metal and was compared to the volume of hydrogen in the deposited metal of arc- and HLA-welded specimens.

The obtained results of investigations show that under the mentioned conditions and methods of welding the ultra-low concentrations of diffusion hydrogen content are observed, namely: $0.2-0.3$ and $0.4 \mathrm{ml} / 100 \mathrm{~g}$, respectively, in the deposited metal of specimens, produced using arc and hybrid methods. In laser welding the diffusion hydrogen content in the molten metal is even lower and amounts to $0.07 \mathrm{ml} / 100 \mathrm{~g}$.

In conclusion, it should be noted that comparative evaluation of properties of butt welded joints of steel N-A-XTRA-70 produced using arc, laser and hybrid method with wire Union NiMoCr of $1 \mathrm{~mm}$ diameter in the mixture of $\mathrm{Ar}+\mathrm{CO}_{2}$ showed that hybrid welding allows providing a sufficiently high level of mechanical properties of welded joints, low content of diffusion hydrogen in weld metal from the point of view of ensuring the high resistance to cold crack formation.

1. Musiyachenko, V.F. (1976) Bases of welding metallurgy and technology of high-strength low-alloy steels: Course of lectures for specialists-welders. In: Int. seminar-practical training of UN on welding. Kiev: Naukova Dumka.

2. Musiyachenko, V.F., Mikhoduj, L.I. (1987) Arc welding of high-strength alloy steels. Moscow: Mashinostroenie.

3. Pokhodnya, I.K., Shvachko, V.I. (1997) Physical nature of hydrogen induced cold cracks in welded joints of high-strength structural steels. Avtomatich. Svarka, 5, 3-10.

4. Markashova. L.I., Poznyakov, V.D., Berdnikova, E.N. et al. (2014) Structure and properties of high-strength steel joints under external static loading. In: Transact. on building, materials science, machine-building, Issue 73, 213-219. Dnepropetrovsk: PGASA.

5. Moore, P.L., Howse, D.S., Wallach, E.R. (2004) Microstructures and properties of laser/arc hybrid welds and autogenous laser welds in pipeline steels. Sci. and Techn. of Welding and Joining, Vol. 9, Issue 4, 314-322.

6. Kah, O., Salminen, A., Martikainen, J. (2010) Laser-arc hybrid welding processes (Review). The Paton Welding J., 6, 32-40.

7. Atabaki, M., Ma, J., Yang, G. et al. (2014) Hybrid laser/arc welding of advanced high strength steel in different butt joint configurations. Materials and Design, 64, 573-587.

8. Shelyagin, V.D., Khaskin, V.Yu., Bernatsky, A.V. et al. (2010) Prospects of application of laser and hybrid technologies of welding steels to increase service life of pipelines. The Paton Welding J., 10, 29-32.

9. Gu, X.Y., Duan, Z.Z., Gu, X.P. et al. (2015) Microstructure and mechanical properties of laser-MAG hybrid welded thick-section weathered steel joint. Int. J. Advanced Manufact. Techn., Vol. 81, Issue 5, 825-831.

10. Grigoryants, A.G. (2015) Special features of laser welding using fibre and $\mathrm{CO}_{2}$ lasers. Welding Int., Vol. 29, Issue 12, 968-973. 